\title{
Synthesis of Prostacyclin from Platelet-derived Endoperoxides by Cultured Human Endothelial Cells
}

\author{
aAron J. Marcus, Babette B. Weksler, Eric A. Jaffe, and M. Johan Broekman, \\ Divisions of Hematology-Oncology, Departments of Medicine, New York \\ Veterans Administration Hospital, New York 10010; and Cornell University \\ Medical College, New York 10021
}

A B S T R A C T We have previously shown that aspirintreated endothelial cells synthesize prostacyclin $\left(\mathrm{PGI}_{2}\right)$ from the purified prostaglandin endoperoxide $\mathrm{PGH}_{2}$ (1978. J. Biol. Chem. 253: 7138). To ascertain whether aspirin-treated endothelial cells produce $\mathrm{PGI}_{2}$ from endoperoxides released by stimulated platelets, $\left[{ }^{3} \mathrm{H}\right]$ arachidonic acid-prelabeled platelets were reacted in aggregometer cuvettes with the calcium ionophore A 23187, thrombin, or collagen in the presence of aspirin-treated endothelial cell suspensions. This procedure permitted thin-layer radiochromatographic quantitation of $\left[{ }^{3} \mathrm{H}\right] \mathrm{PGI}_{2}$ as $\left[{ }^{3} \mathrm{H}\right] 6-$ keto- $\mathrm{PGF}_{1 \alpha}$ and $\left[{ }^{3} \mathrm{H}\right]$ thromboxane $\mathrm{A}_{2}\left(\mathrm{TXA}_{2}\right)$ as $\left[{ }^{3} \mathrm{H}\right] \mathrm{TXB}_{2}$, as well as analysis of platelet aggregation responses in the same sample. In the presence of aspirin-treated endothelial cells, platelet aggregation in response to all three agents was inhibited. $\left[{ }^{3} \mathrm{H}\right] 6-$ keto- $\mathrm{PGF}_{1 \alpha}$ was recovered from the supernates of the combined cell suspensions after stimulation by all three agents. The order of $\mathrm{PGI}_{2}$ production initiated by the stimuli was ionophore $>$ thrombin $>$ collagen. The amounts of platelet $\left[{ }^{3} \mathrm{H}\right] \mathrm{TXB}_{2}$ recovered were markedly reduced by the addition of aspirin-treated endothelial cells. In separate experiments, 6-keto- $\mathrm{PGF}_{1 \alpha}$ and $\mathrm{TXB}_{2}$ were quantitated by radioimmunoassay; the results paralleled those obtained with the use of radiolabeling. The quantity of 6-keto- $\mathrm{PGF}_{1 \alpha}$ measured by radioimmunoassay represented amounts of $\mathrm{PGI}_{2}$ sufficient to inhibit platelet aggregation. These results were obtained when

This work was presented in part at the Annual Meeting of the American Society of Hematology, Phoenix, Ariz., 1-4 December 1979, and published in abstract form in 1979. Blood. 54(Suppl. 1): 290a.

Dr. Jaffe is the recipient of a National Institutes of Health Research Career Development Award 1 KO4 HL 00237 and a Career Scientist Award from the Irma T. Hirschl Trust. Dr. Broekman is a Senior Investigator of the New York Heart Association.

Received for publication 11 February 1980 and in revised form 27 June 1980.
200,000 platelets/ $\mu \mathrm{l}$ were combined with $3,000-6,000$ aspirin-treated endothelial cells/ $\mu$ l. At higher platelet levels the proportion of 6-keto-PGF $1 \alpha$ to $\mathrm{TXB}_{2}$ decreased and platelet aggregation occurred. Control studies indicated that aspirin-treated endothelial cells could not synthesize $\mathrm{PGI}_{2}$ from exogenous radioactive or endogenous arachidonate when stimulated with thrombin. Therefore the endothelial cell suspensions could only have used endoperoxides from stimulated platelets.

Thus, under our experimental conditions, production by endothelial cells of $\mathrm{PGI}_{2}$ from endoperoxides derived from activated platelets could be demonstrated by two independent methods. These experimental conditions included: $(a)$ enhanced platelet-endothelial cell proximity, as attainable in stirred cell suspensions; $(b)$ use of increased endothelial cell/platelet ratios; and (c) utilization of arachidonate of high specific activity in radiolabeling experiments. Furthermore, when a mixture of platelets and endothelial cells that were not treated with aspirin was stimulated with thrombin, more than twice as much 6-keto-PGF ${ }_{1 \alpha}$ was formed than when endothelial cells were stimulated alone. These results indicate that endothelial cells can utilize platelet endoperoxides for $\mathrm{PGI}_{2}$ formation to a significant extent.

\section{INTRODUCTION}

Prostacyclin $\left(\mathrm{PGI}_{2}\right)^{1}(1)$ and thromboxane $\mathrm{A}_{2}\left(\mathrm{TXA}_{2}\right)$ (2) are the main products of the cyclooxygenase pathways in endothelial cells and platelets, respectively. $\mathrm{PGI}_{2}$ is a strong vasodilator and inhibitor of platelet aggregation. TXA ${ }_{2}$ is a powerful vasoconstrictor and a stimulator of platelet aggregation. $\mathrm{PGI}_{2}$ and $\mathrm{TXA}_{2}$ are enzymati-

\footnotetext{
${ }^{1}$ Abbreviations used in this paper: ASA, acetylsalicylic acid (aspirin); $\mathrm{PGE}_{2}$, prostaglandin $\mathrm{E}_{2} ; \mathrm{PGI}_{2}$, prostacyclin; PRP, platelet-rich plasma; 6-keto-PGF , $_{1 \alpha}$ 6-keto-prostaglan$\operatorname{din} \mathrm{F}_{1 \alpha}$; TLC, thin-layer chromatography; TSG, Tris-salineglucose buffer; $\mathrm{TXA}_{2}$, thromboxane $\mathrm{A}_{2} ; \mathrm{TXB}_{2}$, thromboxane $\mathrm{B}_{2}$.
} 
cally derived from a common precursor, the unstable prostaglandin endoperoxide $\mathrm{PGH}_{2}$. Bunting and associates $(3,4)$ had suggested that a biochemical interaction took place between platelets and vessel walls in which endoperoxides from stimulated platelets were also used by the vessels to form $\mathrm{PGI}_{2}$. In this manner a balance might be maintained between the proaggregatory effect of $\mathrm{TXA}_{2}$ and the antiaggregatory action of $\mathrm{PGI}_{2}$ (see reference 5 for review).

We previously demonstrated that exogenously added radioactive $\mathrm{PGH}_{2}$ was converted to $\mathrm{PGI}_{2}$ by endothelial cell monolayers (6). In the present study we show that stimulated $\left[{ }^{3} \mathrm{H}\right]$ arachidonate-labeled platelets can serve as a source of endoperoxide for $\mathrm{PGI}_{2}$ synthesis by endothelial cells. This was demonstrated with the use of $\left[{ }^{3} \mathrm{H}\right]$ arachidonate-labeled platelets and radio thin-layer chromatography (TLC), as well as with unlabeled platelets and radioimmunoassay.

\section{METHODS}

Platelet collection and processing. Platelet-rich plasma (PRP) was prepared in a plastic pack system as previously described (7). Samples of PRP were removed for evaluation of the burst of $\mathrm{O}_{2}$ consumption after stimulation with collagen (7). The latter was used as a criterion for activity of platelet cyclooxygenase.

An average of $80 \mathrm{ml}$ PRP (calculated by weight) containing $\sim 37-50 \times 10^{9}$ platelets was expressed into a satellite bag. 1 $\mathrm{mCi}(5 \mu \mathrm{g})\left[{ }^{3} \mathrm{H}\right]$ arachidonate $(20: 4), 61.0 \mathrm{Ci} / \mathrm{mmol}$ sp act (New England Nuclear, Boston, Mass.), was initially converted to the sodium salt with $0.2 \mathrm{ml} 0.01 \mathrm{M} \mathrm{Na}_{2} \mathrm{CO}_{3}(6)$ and added to PRP in $3 \mathrm{ml}$ Tris-saline-glucose (TSG) buffer (8) containing $1 \%$ albumin. The satellite bag was enclosed in a second plastic bag and incubated in a shaking water bath at 20 oscillations/ min for $1 \mathrm{~h}$ at $37^{\circ} \mathrm{C}(8)$.

After incubation, the labeled PRP was processed as previously described (7). The once-washed platelets were finally suspended in $0.15 \mathrm{M}$ saline and maintained at $4^{\circ} \mathrm{C}$. Radioactivity and platelet count (microhematocrit technique) (9) were then determined. The above procedure yielded an average of $38 \times 10^{9}$ platelets containing $\sim 600,000-800,000 \mathrm{cpm} / 10^{8}$ platelets.

Experiments with endothelial cell monolayers. Human endothelial cells derived from umbilical cords were cultured and acetylsalicylic acid (ASA)-treated as previously described $(6,10)$. Labeled platelets in $5 \mathrm{ml}$ TSG buffer were prewarmed to $37^{\circ} \mathrm{C}(5 \mathrm{~min})$ and then layered over endothelial cells in T-75 flasks. The stimulus was added and the flasks were incubated for $5 \mathrm{~min}$ on a rotating platform at $37^{\circ} \mathrm{C}$. Experiments were terminated by aspirating the supernate from each flask, acidifying it to $\mathrm{pH} 3-3.5$ with $1 \mathrm{M}$ citric acid, and placing it on ice.

Human thrombin (kindly provided by Dr. John Fenton, II) was used at a concentration of $5 \mathrm{U} / \mathrm{ml}$, and collagen at $30 \mu \mathrm{g} /$ $\mathrm{ml}$. In thrombin and collagen experiments $3 \mathrm{mM} \mathrm{Ca}^{++}$was also added. The calcium ionophore A23187 in $2.5 \mu$ l ethanol was added to a final concentration of $1 \mu \mathrm{M}$.

When thromboxane synthetase inhibitors were studied they were added to the platelets during the 5-min preincubation period. Imidazole was added at a concentration of $5 \mathrm{mM}(\mathrm{pH}$ of 7.4). Inhibitor U54701 (9,11-iminoepoxyprosta-5,13 dienoic acid, a gift from Dr. Robert R. Gorman, Upjohn Co.,
Kalamazoo, Mich.) was used at a final concentration of $2 \mu \mathrm{g} / \mathrm{ml}$ and added in $10 \mu \mathrm{l}$ ethanol.

Experiments with endothelial cell suspensions. Endothelial cell monolayers to be used for suspensions were treated with $1 \mathrm{mM}$ ASA ( $30 \mathrm{~min}$ ) and removed with collagenase-EDTA solution (6). The detached cells were pooled, washed twice in Hepes-buffered saline $(0.14 \mathrm{M} \mathrm{NaCl}, 5 \mathrm{mM}$ $\mathrm{KCl}, 15 \mathrm{mM}$ Hepes, pH 7.4, $11 \mathrm{mM}$ glucose) containing $1 \mathrm{mM}$ ASA, suspended in ASA-free TSG buffer $(0.25 \mathrm{ml} / \mathrm{flask})$, and maintained at $22^{\circ} \mathrm{C}$

Labeled platelets and TSG buffer (plus inhibitors when used) were preincubated at $37^{\circ} \mathrm{C}(5 \mathrm{~min})$ in a total volume of $0.25 \mathrm{ml}$ in siliconized aggregometer cuvettes containing stirring bars. A $0.25-\mathrm{ml}$ sample of endothelial cell suspension was added and cuvettes were placed in the aggregometer. 1 min after endothelial cell addition, stimuli were added and aggregation was recorded over a 5-min period. Endothelial cells did not interfere with light transmission in the aggregometry studies. Controls wherein platelets alone were stimulated, were carried out after combined platelet-endothelial cell suspensions were tested.

Reactions were stopped by adding $5 \mu \mathrm{l} \mathrm{M}$ citric acid, cooling the tubes to $4^{\circ} \mathrm{C}$, and centrifuging them at $2,000 \mathrm{~g}$ for 20 min. Supernates were aspirated with siliconized Pasteur pipettes and processed for lipid studies.

For radioimmunoassay studies, reactions were stopped by placing the tubes on ice. Cells were removed by rapid centrifugation in a Beckman microfuge (Beckman Instruments, Inc., Spinco Div., Palo Alto, Calif.) for $3 \mathrm{~min}$ at $4^{\circ} \mathrm{C}$. Supernates were removed and stored at $-20^{\circ} \mathrm{C}$.

Lipid analyses. 3.5 vol methanol:chloroform (5:2) were added to the supernates from either monolayer flasks or tube suspensions. Mixtures were vortexed and stored at $-60^{\circ} \mathrm{C}$. The tubes were later brought to room temperature and a modified Bligh and Dyer lipid extraction was continued (11). The extracts were dried and taken to a volume of $0.1 \mathrm{ml}$ with chloroform:methanol $(2: 1)$ and aliquots removed for scintillation counting (1). TLC (double development), scanning, and quantitation techniques have been described previously $(1,6)$.

Control experiments were carried out to ascertain whether 6,15-diketo $P_{1 \alpha} F_{1 \alpha}$ was being formed in addition to 6-ketoprostaglandin $F_{1 \alpha}$ (6-keto-PGF ${ }_{1 \alpha}$ ) (Wong et al. [12]). Intact and sonicated endothelial cells were incubated $\left(5 \mathrm{~min}, 37^{\circ} \mathrm{C}\right)$ with $\left[{ }^{3} \mathrm{H}\right] \mathrm{PGI}_{2}$ (kindly provided by Dr. David Ahern, New England Nuclear). Cofactors were added to the sonicates (12). RadioTLC analysis indicated that the $\left[{ }^{3} \mathrm{H}\right] \mathrm{PGI}_{2}$ was not metabolized to 6,15-diketo-PGF ${ }_{1 \alpha}$. In addition, $\left[{ }^{3} \mathrm{H}\right] \mathrm{PGE}_{2}$ was used as an alternate substrate to detect 15-hydroxyprostaglandin dehydrogense activity, and no 15-keto- $\mathrm{PGE}_{2}$ was detected.

6-keto $\mathrm{PGF}_{1 \alpha}$ was not detected when radiolabeled platelet suspensions were stimulated in the absence of endothelial cells. The major cyclooxygenase product in activated platelet suspensions was $\mathrm{TXA}_{2}$, which we measured as $\mathrm{TXB}_{2}$ by both radioactivity and radioimmunoassay.

Studies of ASA inhibition of PGI ${ }_{2}$ synthesis. Endothelial cells were treated with $1 \mathrm{mM}$ ASA as outlined above, followed immediately $(0 \mathrm{~min})$ by $\left[{ }^{3} \mathrm{H}\right]$ arachidonate, $10.9 \mu \mathrm{M}(862,049$ cpm), $\mathrm{Ca}^{++}(3 \mathrm{mM})$, and thrombin $(5 \mathrm{U} / \mathrm{ml})$. After a 5-min incubation period samples of the supernates were processed for lipids as described above. The procedure was repeated on samples from the ASA-treated stock suspension 30 and 90 min later. This control protocol was carried out as part of all experiments. Comparable controls were carried out in the radioimmunoassay experiments. The $\mathrm{PGI}_{2}$ synthetase system of these ASA-treated endothelial cells was functional, as demonstrated by formation of 6-keto-PGF $1 \alpha(62 \%$ yield) fol- 
lowing addition of $\left[{ }^{14} \mathrm{C}\right] \mathrm{PGH}_{2}$ to the cell suspensions as previously described (6).

Radioimmunoassays for 6-keto- $P G F_{1 \alpha}$ and $T X B_{2}$. A radioimmunoassay for 6-keto-PGF - $_{1 \alpha}$ was developed in our laboratory using antisera raised in rabbits against synthetic 6-keto$\mathrm{PGF}_{1 \alpha}$ conjugated to keyhole limpet hemocyanin. ${ }^{2} \mathrm{PGI}_{2}$ in the supernates of cell suspensions was converted to 6-keto-PGF by acidification to $\mathrm{pH} 3$ with $1 \mathrm{~N} \mathrm{HCl}$ and subsequent neutralization, or by incubation for $1 \mathrm{~h}$ at $37^{\circ} \mathrm{C}$. Radioimmunoassay was performed by incubating $100 \mu \mathrm{l}$ of diluted test sample (in $50 \mathrm{mM}$ Hepes buffer, $\mathrm{pH} 7.5$, containing $0.2 \%$ bovine serum albumin), $100 \mu \mathrm{l}$ of antiserum at a dilution of 1 to 3,200 , and $100 \mu \mathrm{l}$ of $\left[{ }^{3} \mathrm{H}\right] 6-$ keto-PGF ${ }_{1 \alpha}(10,000 \mathrm{dpm}, 100 \mathrm{Ci} /$ mmol, sp act, New England Nuclear). Following incubation at $20^{\circ} \mathrm{C}$ for $18 \mathrm{~h}$, the bound radioactivity was separated from residual-free radioactivity by adding $100 \mu \mathrm{l}$ of a $1 \%$ suspension of protein A-containing Staphylococcus aureus (Pansorbin, Calbiochem-Behring Corp., American Hoechst Corp., San Diego, Calif.), incubating for $1 \mathrm{~h}$ at $20^{\circ} \mathrm{C}$, and centrifuging. Aliquots of the supernate were then counted in a liquid scintillation counter. Standard curves with 6-keto-PGF ${ }_{1 \alpha}$ were run with each assay and were superimposable with standard curves using $\mathrm{PGI}_{2}$. Half displacement of labeled $\left[{ }^{3} \mathrm{H}\right] 6-$ keto$\mathrm{PGF}_{1 \alpha}$ was achieved at $60 \mathrm{pg} / \mathrm{sample}$. This assay had low crossreactivities with other prostaglandins similar to other assays previously reported.

The radioimmunoassay for $\mathrm{TXB}_{2}$ was similarly developed in our laboratory using antiplasmas raised in rabbits against $\mathrm{TXB}_{2}$ conjugated to keyhole limpet hemocyanin. Conditions for the assay were similar to those used in the assay described above, except that the antiplasma was used at a dilution of 1 to 4,800 . Half displacement of labeled $\left[{ }^{3} \mathrm{H}\right] \mathrm{TXB}_{2}(150 \mathrm{Ci} /$ mmol sp act, New England Nuclear) was achieved with 35 $\mathrm{pg} /$ sample.

$\mathrm{TXB}_{2}, \mathrm{PGI}_{2}$, and 6-keto-PGF $\mathrm{P}_{1 \alpha}$ were generous gifts of Dr. John Pike, Upjohn Co.

Studies with platelet lysates. Platelet integrity was monitored by measuring lactic dehydrogenase in supernates as previously described (13). Platelets incubated for $5 \mathrm{~min}$ without stimulation demonstrated $6 \%$ lysis. Following thrombinor collagen-stimulation, lactic dehydrogenase values were unchanged. Addition of ionophore resulted in 27\% lysis. To assess the effect of lysed platelets on $\mathrm{PGI}_{2}$ synthesis by endothelial cells, control experiments were carried out in which 5 , 10 , and $40 \%$ of the platelet suspensions added to endothelial cells consisted of lysates. The lysates were prepared by rapidly freezing and thawing platelet suspensions three times. Lactic dehydrogenase measurements on the latter indicated $73 \%$ lysis. In no instance did the presence of a platelet lysate increase 6-keto- $\mathrm{PGF}_{1 \alpha}$ formation as measured by radioimmunoassay. For example, the quantity of 6-keto-PGF $1 \alpha$ produced by ASA-treated endothelial cells in the presence of a platelet suspension containing $40 \%$ platelet lysate following thrombin stimulation, was $5.5 \mathrm{ng} / 0.5 \mathrm{ml}$ incubation mixture. In the presence of a normal platelet suspension these endothelial cells produced $8.4 \mathrm{ng} 6$-keto-PGF ${ }_{10} / 0.5 \mathrm{ml}$. In an additional experiment $40 \%$ platelet lysate was added to the usual platelet number to compensate for platelet dilution by the lysate. In this instance $6.4 \mathrm{ng}$ of 6 -keto-PGF ${ }_{1 \alpha}$ was measured per $0.5 \mathrm{ml}$ compared with the $8.4 \mathrm{ng} / 0.5 \mathrm{ml}$ in the control containing no lysate. Stimulus-associated lysis was studied at two concentrations of ionophore, 1 and $0.3 \mu \mathrm{M}$. The higher concentration of ionophore induced a 12 -fold increase in 6 -

${ }^{2}$ Levin, R., E. A. Jaffe, B. B. Weksler, and K. Tack-Goldman. Manuscript in preparation.
keto-PGF $\mathrm{P}_{10}$ production, but only a 1.8 -fold increase in lactic dehydrogenase release. Thus, $\mathrm{PGI}_{2}$ production could not be correlated with the degree of platelet lysis induced by this stimulus.

\section{RESULTS}

Effects of ASA on prostaglandin production by endothelial cells. When non-ASA-treated endothelial cell suspensions were stimulated with thrombin in the presence of $\left[{ }^{3} \mathrm{H}\right]$ arachidonic acid (20:4), the major radiolabeled product in the supernate was 6-keto$\mathrm{PGF}_{1 \alpha}$. The supernate also contained prostaglandins $F_{2 \alpha}, E_{2}, D_{2}$, hydroxy acids (including 12L-hydroxy5,8,10-heptadecatrienoic acid, HHT), and free arachidonate (Table I). 6-keto-PGF - $_{1 \alpha}$ was also identified in parallel experiments by radioimmunoassay. When ASA-treated endothelial cell suspensions were stimulated with thrombin in the presence of $\left[{ }^{3} \mathrm{H}\right]-$ arachidonic acid before $(0 \mathrm{~min})$, during $(30 \mathrm{~min})$, and at the conclusion of each experiment, no radiolabeled 6-keto-PGF - $_{1 \alpha}$ was found (Table I). Radioimmunoassay similarly demonstrated that ASA treatment of endothelial cells completely inhibited 6-keto- $\mathrm{PGF}_{1 \alpha}$ formation induced by thrombin or ionophore. Although the final test sample noted in Table I was studied at $90 \mathrm{~min}$, experimental protocols were completed within 20-60 min. Thus, ASA-inhibited endothelial cells did not recover their cyclooxygenase activity in the course of the experiments.

An additional control experiment to evaluate possible endothelial cell recovery from ASA treatment was performed. When ASA-treated radiolabeled platelets were stimulated with thrombin in the presence of ASA-inhibited endothelial cell suspensions, radioactive arachidonic acid was released from the platelets (data not shown). However, no 6-keto-PGF ${ }_{1 \alpha}$ was formed by the endothelial cells. This is further evidence that the ASA-inhibited endothelial cells could not metabolize arachidonic acid to $\mathrm{PGI}_{2}$ during the experimental procedure.

Stimulated platelets as a source of endoperoxide for $P G I_{2}$ synthesis. Combined suspensions of radiolabeled platelets $(200,000 / \mu \mathrm{l})$ and ASA-treated endothelial cells $(3,000-6,000 / \mu \mathrm{l})$ were stimulated with either ionophore, thrombin or collagen, in aggregometer cuvettes, and the response was recorded. In radiolabeling experiments cuvette contents were then processed for lipid analysis as described in Methods. When nonlabeled platelets were studied, supernates were processed for radioimmunoassay of 6-keto-PGF ${ }_{1 \alpha}$ and $\mathrm{TXB}_{2}$. Thus, the platelet aggregation response and formation of $\mathrm{PGI}_{2}$ and $\mathrm{TXA}_{2}$ were evaluated in the same sample. In the absence of endothelial cells, 6-keto$\mathrm{PGF}_{1 \alpha}$ was not detected. Furthermore, incubation of unstimulated radiolabeled platelets with ASA-treated 
TABLE I

TLC-Radiochromatographic Analysis of Effect of ASA on Prostaglandin Production from [ ${ }^{3} \mathrm{H}$ Arachidonic Acid by Thrombin-stimulated Endothelial Cells*

\begin{tabular}{lrrrrrrrr}
\hline \multicolumn{1}{c}{ No ASA } & \multicolumn{2}{c}{ ASA 0 min } & \multicolumn{2}{c}{ ASA 30 min } & \multicolumn{2}{c}{ ASA 90 min } \\
\hline & $c p m \ddagger$ & $\% \$$ & $c p m$ & $\%$ & $c p m$ & $\%$ & $c p m$ & $\%$ \\
6-keto-PGF & & & & & & & \\
PGF $_{2 \alpha}$ & 116,008 & $(65.5)$ & 103 & $(0.7)$ & 97 & $(0.8)$ & 118 & $(1.0)$ \\
PGE $_{2}$ & 30,484 & $(17.2)$ & 132 & $(0.9)$ & 172 & $(1.3)$ & 196 & $(1.7)$ \\
PGD $_{2}$ & 6,060 & $(3.4)$ & 162 & $(1.1)$ & 132 & $(1.0)$ & 157 & $(1.3)$ \\
Hydroxy acids & 2,119 & $(1.2)$ & 166 & $(1.1)$ & 227 & $(1.8)$ & 253 & $(2.1)$ \\
Arachidonic acid & 6,559 & $(3.7)$ & 1,448 & $(10.3)$ & 1,351 & $(10.5)$ & 1,376 & $(11.6)$ \\
& 3,220 & $(1.8)$ & 11,168 & $(79.2)$ & 10,125 & $(79.0)$ & 8,901 & $(74.9)$ \\
\hline
\end{tabular}

* To $5.5 \times 10^{6}$ endothelial cells, treated or not treated with $1 \mathrm{mM} \mathrm{ASA}$, was added [ ${ }^{3} \mathrm{H}$ ]arachidonic acid (final concentration $10.9 \mu \mathrm{M} ; 862,049 \mathrm{cpm}), \mathrm{Ca}^{++}(3 \mathrm{mM})$, and thrombin $(5 \mathrm{U} / \mathrm{ml})$. Total volume was $0.5 \mathrm{ml}$.

$\$$ Total counts in supernate. Note that the supernates from the ASA-treated endothelial cells contain fewer total counts. This is because free and esterified arachidonic acid remains largely associated with the cells, whereas products of the cyclooxygenase pathway (6-keto-PGF ${ }_{1 \alpha}$ and other prostaglandins) are more soluble in the supernate.

$\S$ Percentage of recovered counts minus phospholipid and solvent front. Radioactive areas on TLC plates that did not correspond to standards are not included. In the ASA-treated samples, counts obtained in the 6-keto-PGF ${ }_{1 \alpha}$ areas do not represent a peak of radioactivity.

endothelial cells did not result in $\mathrm{PGI}_{2}$ production. Thus, in the absence of an endoperoxide source, ASAtreated endothelial cells were unable to form $\mathrm{PGI}_{2}$.

Ionophore A23187. Essentially no platelet aggregation occurred when platelets and ASA-treated endothelial cell suspensions were stimulated with ionophore (Fig. 1b), whereas platelets alone responded normally (Fig. la). The TLC radioscan (Fig. 2) of super-

(a)
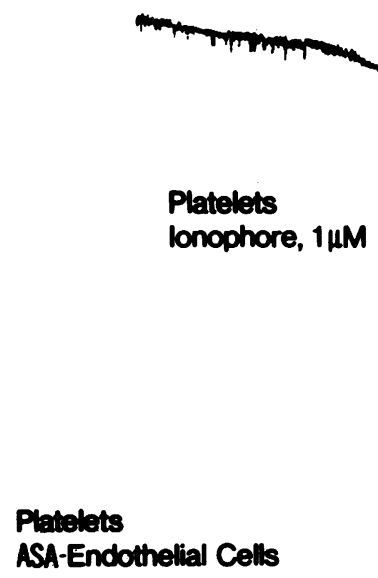

lonophore, 1 $\mu \mathrm{M}$ natant lipids from the sample shown in Fig. lb indicated formation of 6-keto-PGF ${ }_{1 \alpha}$, as did quantitative analysis of the peaks on this TLC plate (Table II). In the absence of ASA-treated endothelial cells (Fig. la), ionophore-treated platelets produced 1.9 times more $\mathrm{TXB}_{2}(24,940 \mathrm{cpm})$ than in their presence $(12,997 \mathrm{cpm})$. In two separate groups of experiments, production of significant quantities of 6-keto- $\mathrm{PGF}_{1 \alpha}$ and $\mathrm{TXB}_{2}$ was demonstrated by radioimmunoassay, corroborating the radiolabeling experiments. For example, a mixture of ASA-treated endothelial cells $\left(2 \times 10^{6}\right)$ and platelets $\left(1 \times 10^{8}\right)$ produced $1.7 \mathrm{ng}$ 6-keto- $\mathrm{PGF}_{1 \alpha}$ and $21.3 \mathrm{ng}$ $\mathrm{TXB}_{2}$ following stimulation with ionophore $(1.0 \mu \mathrm{M})$. It is of interest that no platelet aggregation occurred in the presence of endothelial cells (Fig. Ib), despite formation of relatively large quantities of $\mathrm{TXB}_{2}$.

Thrombin. When compared with controls, plate-

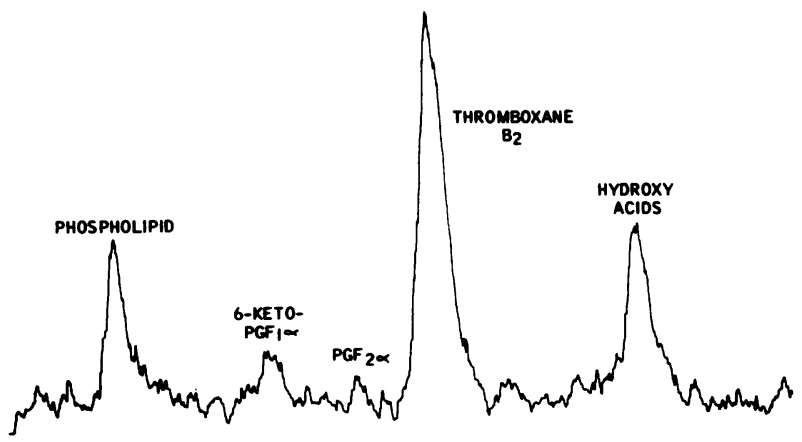

FIGURE 2 Platelets, ASA-treated endothelial cells, and ionophore, $1 \mu \mathrm{M}$. Scan of TLC radiochromatogram of lipids in supernate from the experiment depicted in Fig. 1(b) and quantified in Table II. In contrast, the supernate from the aggregation experiment shown in Fig. la contained 1.9 times more $\mathrm{TXA}_{2}$ than did that from Fig. 1b, and no $\mathrm{PGI}_{2}$. 
TABLE II

TLC-Radiochromatographic Analysis of Products in the Supernate of Combined Suspensions of Radiolabeled Platelets and ASA-treated Endothelial Cells after Stimulation with Ionophore, Thrambin, and Collagen*

\begin{tabular}{lrrrrrr}
\hline \multicolumn{1}{c}{ Product } & \multicolumn{2}{c}{ Ionophore } & \multicolumn{2}{c}{ Thrombin } & \multicolumn{2}{c}{ Collagen } \\
& $c p m !$ & $\% \$$ & $c p m$ & $\%$ & $c p m$ & $\%$ \\
6-keto-PGF $_{1 \alpha}$ & 1,261 & $(5.4)$ & 444 & $(4.1)$ & 60 & $(3.0)$ \\
PGF $_{2 \alpha}$ & 895 & $(3.9)$ & 356 & $(3.3)$ & 73 & $(3.7)$ \\
TXB $_{2}$ & 12,997 & $(56.1)$ & 6,624 & $(61.5)$ & 1,008 & $(51.0)$ \\
PGE $_{2}$ & 845 & $(3.6)$ & 247 & $(2.3)$ & 58 & $(2.9)$ \\
PGD $_{2}$ & 372 & $(1.6)$ & 111 & $(1.0)$ & 58 & $(2.9)$ \\
Hydroxy acids & 4,209 & $(18.2)$ & 1,713 & $(15.9)$ & 451 & $(22.8)$ \\
Arachidonic acid & 142 & $(0.6)$ & 253 & $(2.3)$ & 126 & $(6.4)$ \\
\hline
\end{tabular}

* Total of $1 \times 10^{8}$ platelets $(783,678 \mathrm{cpm})=200,000 / \mu \mathrm{l}$. Total of $3.1 \times 10^{6}$ endothelial cells $=6,238 / \mu \mathrm{l}$. Total volume was $0.5 \mathrm{ml}$. Ionophore $(1 \mu \mathrm{M})$, thrombin $(5 \mathrm{U} / \mathrm{ml})$, collagen $(30$ $\mu \mathrm{g} / \mathrm{ml}), \mathrm{Ca}^{++}(3 \mathrm{mM})$.

\$ Total counts in supernate.

$\S$ Percentage of recovered counts minus phospholipid and solvent front. Radioactive areas on TLC plates that did not correspond to standards are not included. In all samples counts obtained in the 6-keto- $\mathrm{PGF}_{1 \alpha}$ areas represented a peak of radioactivity.

let aggregation responses to thrombin were always markedly reduced in the presence of ASA-treated endothelial cell suspensions (Fig. 3), and production of 6keto-PGF ${ }_{1 \alpha}$ was demonstrable. Table II shows the TLC-radiochromatographic analysis of supernatant lipids from the experiment shown in Fig. 3b. By radioimmunoassay, combined suspensions of ASA-treated endothelial cells $\left(2 \times 10^{6}\right)$ and platelets $\left(1 \times 10^{8}\right)$ generated $0.5 \mathrm{ng} 6$-keto- $\mathrm{PGF}_{1 \alpha}$ and $7.6 \mathrm{ng} \mathrm{TXB}_{2}$, respec-

(a)

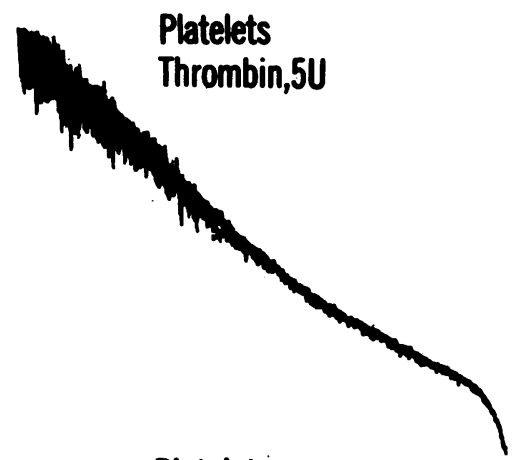

(b)

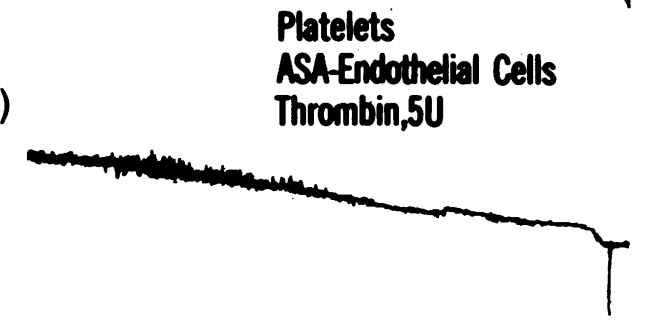

FIGURE 3 (a) Aggregation response of platelets stimulated with thrombin $(5 \mathrm{U} / \mathrm{ml})$. (b) Platelet response to thrombin in the presence of ASA-treated endothelial cells. The supernate from this mixture contained $\mathrm{PGI}_{2}$, as shown in Table II. Total volume of test mixture was $0.5 \mathrm{ml}$. tively, after thrombin addition. As noted with ionophore, inhibition of thrombin-induced platelet aggregation (Fig. 3b) occurred, even in the presence of thromboxane production (Table II). Thrombin-treated platelets generated 1.4 times more thromboxane $(9,555$ cpm) in the absence of ASA-treated endothelial cells than in their presence $(6,624 \mathrm{cpm})$. When measured by radioimmunoassay in a separate experiment the quantities were $16.3 \mathrm{ng}$ and $7.6 \mathrm{ng}$, respectively. When both platelets and endothelial cells were pretreated with ASA and then stimulated with thrombin, no 6keto-PGF ${ }_{1 \alpha}$ was measurable.

Collagen. In the presence of ASA-treated endothelial cells inhibition of aggregation responses to collagen was comparable to that observed with thrombin (Fig. 4). However, smaller quantities of 6-keto$\mathrm{PGF}_{1 \alpha}^{\prime}$ and $\mathrm{TXB}_{2}$ were detected following collagen stimulation than in the case of thrombin or ionophore (Table II). By radioimmunoassay collagen stimulation of the platelet-endothelial cell mixtures resulted in production of $0.1 \mathrm{ng}$ 6-keto- $\mathrm{PGF}_{1 \alpha}$ and $2.5 \mathrm{ng} \mathrm{TXB}_{2}$. As can be seen in Table II and from the radioimmunoassay results, the quantitative profile of endothelial cell $\mathrm{PGI}_{2}$ production was ionophore $>$ thrombin $>$ collagen, and the pattern of thromboxane production by platelets in the combined suspensions followed the same order. In the absence of ASA-treated endothelial cells the quantity of platelet thromboxane recovered in the supernate following collagen stimulation was 5.1 times higher $(5,128 \mathrm{cpm})$ than in their presence $(1,008$ $\mathrm{cpm})$. When measured by radioimmunoassay in a separate experiment the quantities were $9 . \dot{9}$ and $2.5 \mathrm{ng}$, respectively.

Evaluation of the platelet contribution to $\mathrm{PGI}_{2}$ formation by endothelial cells. This series of experi- 
(a)

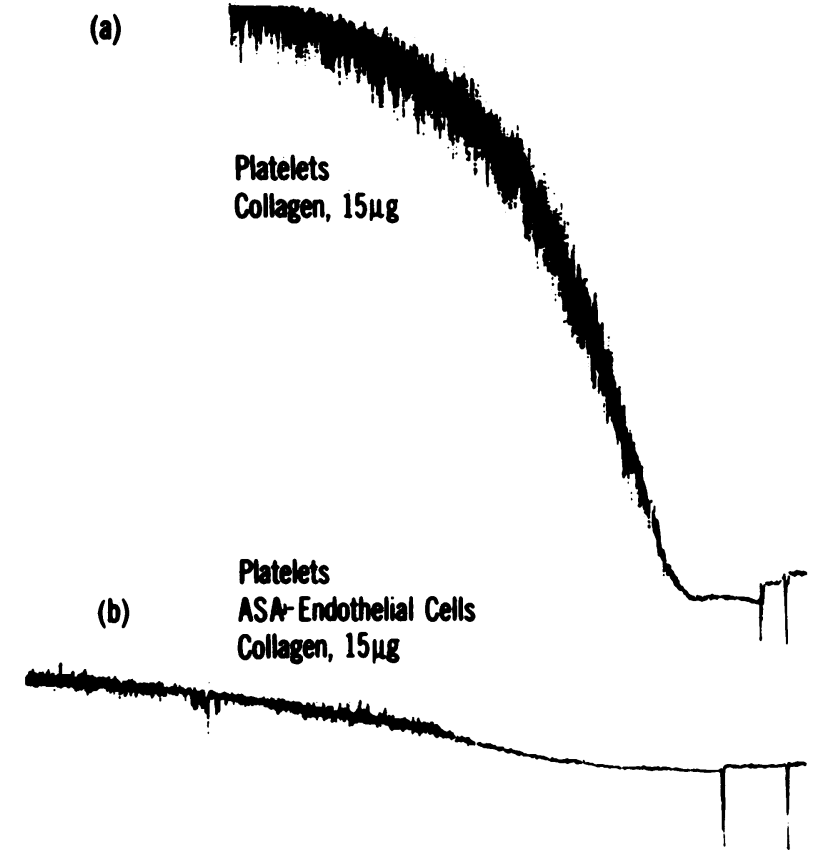

FIGURE 4 (a) Control aggregation curve with collagen (15 $\mu \mathrm{g} /$ cuvette) as the stimulus. (b) Effect of ASA-treated endothelial cells on the platelet response to collagen. The pattern of inhibition was similar to that observed with thrombin. $\mathrm{PGI}_{2}$ formation was demonstrable, as shown in Table II. However, the quantity of radiolabeled 6-keto-PGF ${ }_{10}$ detected was lower than in the thrombin and ionophore experiments. Similar results were obtained in radioimmunoassay experiments. Total volume of test mixture was $0.5 \mathrm{ml}$

ments was carried out in the radioimmunoassay system. When endothelial cells $\left(3 \times 10^{6}\right)$ were stimulated with thrombin in the absence of ASA, $7.7 \mathrm{ng} 6$-ketoPGF $_{1 \alpha}$ were formed. If a mixture of platelets $\left(1 \times 10^{8}\right)$ and non-ASA-treated endothelial cells were stimulated with thrombin, $19.2 \mathrm{ng}$ of 6-keto-PGF ${ }_{1 \alpha}$ were formed (i.e., a 2.5-fold increase).

Endothelial cells from this batch were treated with ASA and added to platelets, which were then the sole source of endoperoxide. Subsequent stimulation with thrombin yielded $8.4 \mathrm{ng}$ 6-keto-PGF ${ }_{1 \alpha}$, which was derived from platelet endoperoxides. This was similar to the quantity produced by non-ASA-treated endothelial cells alone $(7.7 \mathrm{ng})$. Thus, in this system approximately half of the total 6-keto-PGF $\mathrm{F}_{1 \alpha}$ produced by endothelial cell-platelet mixtures was derived from platelet endoperoxides.

Relation of platelet concentration to $\mathrm{PGI}_{2}$ production by ASA-treated endothelial cells. Experiments were carried out wherein $1.45 \times 10^{6}$ endothelial cells $(2,900 / \mu \mathrm{l})$ were combined with either $1 \times 10^{8}$ or $15.5 \times 10^{8}$ platelets $\left(2\right.$ or $\left.31 \times 10^{5} / \mu \mathrm{l}\right)$ and then stimulated with ionophore, thrombin, or collagen. The increase in platelet concentration resulted in formation of greater amounts of both 6-keto-PGF ${ }_{1 \alpha}$ and $\mathrm{TXB}_{2}$ (Table III). However, the production of $\mathrm{TXB}_{2}$ was increased much more than that of 6 -keto- $\mathrm{PGF}_{1 \alpha}$, as shown by the four- to sevenfold increase in the ratio $\mathrm{TXB}_{2} / 6$-keto-PGF ${ }_{1 \alpha}$ (Table III). In another experiment the effect of platelet concentration on the aggregation response was examined. Combining 200,000 platelets/ $\mu$ l with 3,850 ASA-treated endothelial cells $/ \mu$, followed by stimulation with thrombin $(5 \mathrm{U} / \mathrm{ml})$, resulted in inhibition of aggregation comparable to that depicted in Fig. 3b. However, when the platelet concentration was raised to $500,000 / \mu \mathrm{l}$ the inhibitory effect of ASAtreated endothelial cells was lost and a normal aggregation response comparable with that in Fig. 3a ensued.

Studies with ASA-treated endothelial cell monolayers and suspensions. Ionophore stimulation of radiolabeled platelets added to ASA-treated endo-

TABLE III

TLC-Radiochromatographic Analysis of Effect of Platelet Concentration on Production of PGI $I_{2}$ and $\mathrm{TXA}_{2}$ by Combined Suspensions of Platelets and ASA-treated Endothelial Cells

\begin{tabular}{|c|c|c|c|c|c|c|}
\hline \multirow[t]{2}{*}{ Stimulus* } & \multirow{2}{*}{$\frac{\begin{array}{c}\text { Platelet } \\
\text { concentration } / \mu l\end{array}}{\mu l}$} & \multicolumn{2}{|c|}{ 6-keto-PGF ${ }_{1 \alpha}$} & \multicolumn{2}{|c|}{$\mathrm{TXB}_{2} \mathrm{t}$} & \multirow[t]{2}{*}{$\mathrm{TXB}_{2} / 6$-keto-PGF ${ }_{1 a}$} \\
\hline & & $c p m \S$ & $\%$ & $c \mathrm{~mm}$ & $\%$ & \\
\hline Ionophore & $\begin{array}{c}2 \times 10^{54} \\
31 \times 10^{5 * *}\end{array}$ & $\begin{array}{l}2,023 \\
5,586\end{array}$ & $\begin{array}{l}(8.6) \\
(2.2)\end{array}$ & $\begin{array}{r}9,958 \\
193,272\end{array}$ & $\begin{array}{l}(42.3) \\
(74.5)\end{array}$ & $\begin{array}{r}4.9 \\
34.6\end{array}$ \\
\hline Thrombin & $\begin{array}{r}2 \times 10^{5} \\
31 \times 10^{5}\end{array}$ & $\begin{array}{r}561 \\
3,167\end{array}$ & $\begin{array}{l}(6.1) \\
(2.0)\end{array}$ & $\begin{array}{r}4,724 \\
114,311\end{array}$ & $\begin{array}{l}(51.1) \\
(72.5)\end{array}$ & $\begin{array}{r}8.4 \\
36.1\end{array}$ \\
\hline Collagen & $\begin{array}{r}2 \times 10^{5} \\
31 \times 10^{5}\end{array}$ & $\begin{array}{r}79 \\
125\end{array}$ & $\begin{array}{l}(5.6) \\
(1.6)\end{array}$ & $\begin{array}{r}422 \\
4,576\end{array}$ & $\begin{array}{l}(29.9) \\
(61.3)\end{array}$ & $\begin{array}{r}5.3 \\
36.6\end{array}$ \\
\hline
\end{tabular}

* Ionophore $(1 \mu \mathrm{M})$, thrombin $(10 \mathrm{U} / \mathrm{ml})$, collagen $(30 \mu \mathrm{g} / \mathrm{ml}), \mathrm{Ca}^{++}(3 \mathrm{mM})$. Total volume was $0.5 \mathrm{ml}$.

I Includes a small quantity of $\mathrm{PGE}_{2}$ that overlapped with $\mathrm{TXB}_{2}$ on these TLC plates.

$\$$ Total counts in supernate.

"Percentage of recovered counts minus phospholipid and solvent front.

I Total of $1 \times 10^{8}$ platelets $(623,107 \mathrm{cpm})$; total of $1.45 \times 10^{6}$ endothelial cells.

** Total of $15.5 \times 10^{8}$ platelets $(9,346,605 \mathrm{cpm})$; total of $1.45 \times 10^{6}$ endothelial cells. 
thelial cell monolayers resulted in less $\mathrm{PGI}_{2}$ production than that observed in the same experiment with platelets and ASA-endothelial cell suspensions (491 vs. 782 cpm). A similar effect was noted when thrombin was the stimulus. Monolayer experiments carried out in the presence of the thromboxane synthetase inhibitors imidazole and U54701 resulted in an increase in $\mathrm{PGI}_{2}$ production as reported by others (14-16). In the case of ionophore stimulation, counts in the 6-keto- $\mathrm{PGF}_{1 \alpha}$ TLC peak increased from 491 to $3,826 \mathrm{cpm}$ with imidazole, and to $4,177 \mathrm{cpm}$ with U54701. The effect of imidazole and U54701 was also apparent when platelets and ASA-treated endothelial cell suspensions were used. With ionophore, the counts in the 6-keto-PGF $\mathrm{F}_{1 a}$ area rose from 782 to $12,030 \mathrm{cpm}$ in the presence of imidazole, and to $10,847 \mathrm{cpm}$ with U54701. Results with thrombin in the presence of $\mathrm{TXA}_{2}$ synthetase inhibitors were comparable to those with ionophore in that $\mathrm{PGI}_{2}$ production increased 10 -fold in the $\mathrm{ASA}$ treated endothelial cell monolayers and 14-fold in the suspensions.

\section{DISCUSSION}

Although endothelial cells can synthesize $\mathrm{PGI}_{2}$ from endogenous precursors (17-19) or from exogenously provided endoperoxides $(6)$ or arachidonate $(1,6,16)$, $\mathrm{PGI}_{2}$ synthesis by endothelial cells from platelet-derived endoperoxides has been demonstrated only in the presence of thromboxane synthetase inhibitors (1416). These results indicated to us that utilization of platelet endoperoxides for $\mathrm{PGI}_{2}$ synthesis by ASAtreated endothelial cells might be possible even in the absence of thromboxane synthetase inhibitors.

We used two independent methods for detection of 6-keto- $\mathrm{PGF}_{1 \alpha}$, radiolabeling and radioimmunoassay. The radiometric experiments made it possible to follow the metabolism of platelet-derived endoperoxides by ASA-treated endothelial cells. The radioimmunoassay provided quantitative information on the total amount of 6-keto- $\mathrm{PGF}_{1 \alpha}$ generated. As previously reported (18), addition of $50 \mathrm{pg} \mathrm{P^{2 }}$ to $0.5 \mathrm{ml} \mathrm{PRP} \mathrm{inhibited} \mathrm{aggre-}$ gation induced by $0.3 \mathrm{mM}$ sodium arachidonate. In addition, the radioimmunoassays allowed us to compare the quantity of 6-keto- PGF $_{1 \alpha}$ generated endogenously by the endothelial cells alone with that derived from platelet endoperoxides.

The high specific activity of $\left[{ }^{3} \mathrm{H}\right]$ arachidonate for radiolabeling permitted studies of platelets in the range of $200,000 / \mu \mathrm{l}$ and increased the sensitivity of the TLC detection system. Use of suspensions of endothelial cells in preference to monolayers enhanced platelet-endothelial cell proximity by concentrating the components in a small volume and permitted adequate mixing. Under these conditions both aggregometry and analysis of products could be performed on the same sample.

When low endothelial cell-to-platelet ratios $(\sim 1: 1,000)$ were used, production of 6 -keto- $\mathrm{PGF}_{1 \alpha}$ relative to $\mathrm{TXB}_{2}$ was low and the platelets aggregated upon stimulation. The ratio of endothelial cells to platelets was then increased to $\sim 1: 50$ in order to approach that which occurs in vivo. The surface area of an endothelial cell is $\sim 30 \times 50 \mu \mathrm{m}\left(1,500 \mu \mathrm{m}^{2}\right)(10)$ and the area of the capillary vasculature in a $70-\mathrm{kg}$ man is $\sim 1,000 \mathrm{~m}^{2}(20)$. Thus the capillary vasculature of the average subject is lined by $\sim 7 \times 10^{11}$ endothelial cells. Assuming a blood volume of $5,000 \mathrm{ml}$ and a platelet count of $\sim 300,000 / \mu \mathrm{l}$, the vasculature would contain $1.5 \times 10^{12}$ platelets. Therefore in vivo the ratio of endothelial cells to platelets, at least in capillaries, approaches 1:1. At our endothelial cell to platelet ratio of $1: 50, \mathrm{PGI}_{2}$ was produced and platelet aggregation was inhibited.

ASA treatment of endothelial cells. Experiments initially carried out with non-ASA-treated endothelial cell suspensions stimulated with thrombin in the presence of $\left[{ }^{3} \mathrm{H}\right]$ arachidonate indicated that 6 -keto- $\mathrm{PGF}_{1 \alpha}$ accounted for $66 \%$ of the $\left[{ }^{3} \mathrm{H}\right]$ arachidonic acid metabolites formed (Table I). Following treatment with ASA the capacity of the endothelial cells to synthesize $\mathrm{PGI}_{2}$ from arachidonate was lost and was not recovered during the experiments. This was ascertained by both radiolabeling and radioimmunoassay studies. However, the $\mathrm{PGI}_{2}$ synthetase system of ASA-treated endothelial cells remained intact, as evidenced by 6-keto$\mathrm{PGF}_{1 \alpha}$ production $(\sim 62 \%)$ when $\left[{ }^{14} \mathrm{C}^{\mathrm{PGGH}} \mathrm{PG}_{2}\right.$ was used as substrate (6; see also Methods). That the aspirintreated endothelial cells did not recover their cyclooxygenase activity during the experiment was also borne out by the absence of detectable 6-keto-PGF ${ }_{1 \alpha}$ when $\left[{ }^{3} \mathrm{H}\right]$ arachidonate was released from thrombin-stimulated, ASA-treated platelets.

$P I_{2}$ synthesis from platelet endoperoxides. Ionophore is a strong inducer of platelet aggregation and $\mathrm{TXA}_{2}$ production as well as of endothelial cell $\mathrm{PGI}_{2}$ synthesis (18). In the experiments reported here ionophore was the most potent stimulus of $\mathrm{PGI}_{2}$ production. Inhibition of platelet aggregation in mixtures of ASAtreated endothelial cells and platelets was also the most pronounced with ionophore (Fig. 1). While thrombin was a stronger stimulus for both $\mathrm{PGI}_{2}$ and $\mathrm{TXA}_{2}$ production than was collagen, the inhibitory effects of ASA-treated endothelial cells on thrombin- and collagen-induced aggregation were similar (Figs. 3 and 4).

When a mixture of platelets and endothelial cells was stimulated by thrombin in an ASA-free system, approximately twice as much 6 -keto-PGF ${ }_{1 \alpha}$ as measured by radioimmunoassay formed than when platelets were omitted. A further experiment indicated that the increase in 6-keto-PGF ${ }_{1 \alpha}$ noted in the presence of platelets was due to transfer of platelet endoperoxides to the endothelial cells. Endothelial cells stimulated by thrombin to produce $\mathrm{PGI}_{2}$ from endogenous sources in the absence of ASA produced no more $\mathrm{PGI}_{2}$ than when ASA-treated endothelial cells were combined with 
platelets as the sole source of endoperoxides. Thus, in our system endothelial cells formed approximately half of their $\mathrm{PGI}_{2}$ from platelet-derived endoperoxides.

In our experiments stimulated platelets synthesized less thromboxane when admixed with ASA-treated endothelial cells than when present in the incubation system alone. A possible explanation is that some of the available platelet endoperoxides were diverted to $\mathrm{PGI}_{2}$ synthesis when ASA-treated endothelial cells were present with the platelets. An additional possibility is that the $\mathrm{PGI}_{2}$ formed by the ASA-treated endothelial cells led to inhibition of platelet aggregation and therefore to a decrease in further $\mathrm{TXA}_{2}$ production.

Inhibition of $\mathrm{TXA}_{2}$ synthesis with imidazole or U54701 presumably resulted in accumulation of endoperoxides (14-16), thereby facilitating $\mathrm{PGI}_{2}$ synthesis by ASA-treated endothelial cells in both monolayers and suspensions. In the presence of $\mathrm{TXA}_{2}$ synthetase inhibitors, ASA-treated endothelial cells generated $\mathrm{PGI}_{2}$ from endoperoxides formed in thrombin-treated platelets, even when albumin was included in the medium. However, in the presence of albumin the quantities of $\mathrm{PGI}_{2}$ formed were lower than in its absence, and there was an increase in $\mathrm{PGD}_{2}$ formation. The latter observations are in agreement with the reported enhanced isomerization of endoperoxides in albumin $(15,21)$. Thus, in order to maximize the sensitivity of the assay systems, albumin was not included in the incubation medium in the remainder of the experiments.

There therefore appear to bè two mechanisms for $\mathrm{PGI}_{2}$ synthesis by cultured human endothelial cells. The first involves synthesis of $\mathrm{PGI}_{2}$, from endogenous precursors, and the second occurs from endoperoxides derived from stimulated platelets. Specific conditions under which one or both mechanisms may be operative have not as yet been established.

\section{ACKNOWLEDGMENTS}

We acknowledge the invaluable assistance of Lenore B. Safier, Harris L. Ullman, Charles R. Dorso, Karen Tack-Goldman and Sheldon Brown.

This work was supported by grants from the Veterans Administration, the National Institutes of Health (HL 1882805 SCOR), the New York Heart Association, and the A. R. Krakower Foundation.

\section{REFERENCES}

1. Weksler, B. B., A. J. Marcus, and E. A. Jaffe. 1977. Synthesis of prostaglandin $I_{2}$ (prostacyclin) by cultured human and bovine endothelial cells. Proc. Natl. Acad. Sci. U. S. A. 74: 3922-3926.

2. Hamberg, M., J. Svensson, and B. Samuelsson. 1975. Thromboxanes: a new group of biologically active com- pounds derived from prostaglandin endoperoxides. Proc. Natl. Acad. Sci. U. S. A. 72: 2994-2998.

3. Bunting, S., R. Gryglewski, S. Moncada, and J. R. Vane. 1976. Arterial walls generate from prostaglandin endoperoxides a substance (prostaglandin X) which relaxes strips of mesenteric and coeliac arteries and inhibits platelet aggregation. Prostaglandins. 12: 897-913.

4. Moncada, S., and J. R. Vane. 1979. Arachidonic acid metabolites and the interactions between platelets and blood-vessel walls. N. Engl. J. Med. 300: 1142-1147.

5. Marcus, A. J. 1979. The role of prostaglandins in platelet function. Progr. Hematol. 11: 147-171.

6. Marcus, A. J., B. B. Weksler, and E. A. Jaffe. 1978. Enzymatic conversion of prostaglandin endoperoxide $\mathrm{H}_{2}$ and arachidonic acid to prostacyclin by cultured human endothelial cells. J. Biol. Chem. 253: 7138-7141.

7. Bressler, N. M., M. J. Broekman, and A. J. Marcus. 1979. Concurrent studies of oxygen consumption and aggregation in stimulated human platelets. Blood. 53: 167-178.

8. Bills, T. K., J. B. Smith, and M. J. Silver. 1976. Metabolism of $\left[{ }^{14} \mathrm{C}\right]$ arachidonic acid by human platelets. Biochim. Biophys. Acta. 424: 303-314.

9. Tollefsen, D. M., J. R. Feagler, and P. W. Majerus. 1974. The binding of thrombin to the surface of human platelets. J. Biol. Chem. 249: 2646-2651.

10. Jaffe, E. A., R. L. Nachman, C. G. Becker, and C. R. Minick. 1973. Culture of human endothelial cells derived from umbilical veins. Identification by morphologic and immunologic criteria. J. Clin. Invest. 52: 2745-2756.

11. Broekman, M. J., R. I. Handin, A. Derksen, and P. Cohen. 1976. Distribution of phospholipids, fatty acids, and platelet factor 3 activity among subcellular fractions of human platelets. Blood. 47: 963-971.

12. Wong, P. Y-K., F. F. Sun, and J. C. McGiff. 1978. Metabolism of prostacyclin in blood vessels. J. Biol. Chem. 253: 5555-5557.

13. Marcus, A. J., D. Zucker-Franklin, L. B. Safier, and H. L. Ullman. 1966. Studies on human platelet granules and membranes. J. Clin. Invest. 45: 14-28.

14. Moncada, S., S. Bunting, K. Mullane, P. Thorogood, J. R. Vane, A. Raz, and P. Needleman. 1977. Imidazole: a selective inhibitor of thromboxane synthetase. Prostaglandins. 13: 611-618.

15. Needleman, P., A. Wyche, and A. Raz. 1979. Platelet and blood vessel arachidonate metabolism and interactions. J. Clin. Invest. 63: 345-349.

16. Baenziger, N. L., P. R. Becherer, and P. W. Majerus. 1979. Characterization of prostacyclin synthesis in cultured human arterial smooth muscle cells, venous endothelial cells and skin fibroblasts. Cell. 16: 967-974.

17. MacIntyre, D. E., J. D. Pearson, and J. L. Gordon. 1978. Localisation and stimulation of prostacyclin production in vascular cells. Nature (Lond.). 271: 549-551.

18. Weksler, B. B., C. W. Ley, and E. A. Jaffe. 1978. Stimulation of endothelial cell prostacyclin production by thrombin, trypsin, and the ionophore A 23187. J. Clin. Invest. 62: $923-930$.

19. Nordøy, A., B. Svensson, and J. C. Hoak. 1978. The inhibitory effect of human endothelial cell monolayers on platelet reactions and its inhibition by aspirin. Thromb. Res. 12: 597-608.

20. Falkow, B., and E. Neil. 1971. Circulation. Oxford University Press, Inc., New York, p. 38.

21. Hamberg, M., and B. B. Fredholm. 1976. Isomerization of prostaglandin $\mathrm{H}_{2}$ into prostaglandin $\mathrm{D}_{2}$ in the presence of serum albumin. Biochim. Biophys. Acta. 431: 189-193. 